\title{
DESAIN MODEL PEMBELAJARAN SIMULASI UNTUK MENANAMKAN NILAI-NILAI ISLAMI DI SMPT MANAHIJUL HUDA TASIKMALAYA
}

\author{
Sinta Setiawati \\ Prodi Pendidikan Seni. Sekolah Pasca Sarjana. Universitas Pendidikan Indonesia. \\ Sintasetia27@gmail.com
}

\begin{abstract}
Abstact
The learning process of dance is now avoided by some schools, because the learning objectives are not comprehensively understood by all parties. But there are some schools in Tasikmalaya that teach dance in their learning process even by applying Islamic values. Islamic values are an important value implanted in the learners to form a good character. By analyzing two schools conducting dance lessons to apply Islamic values, researchers designed a simulated learning model for simulation development conducted at other schools in Tasikmalaya District. The Islamic values applied are derived from the characteristics of Prophet Muhammad SAW, namely sidiq, tabligh, amanah and fatonah. Researchers used the story stimulus of heroes of Islam to turn the story's ideas into motion while the idea of motion developed the motion of Ibing Pencak. Theories used in this research that is koneksionis theory, theory of adolescent development, education theory and others. This research uses Design Based Research method with qualitative approach. This research is done gradually with cycle repetition. There are 4 cycles with 6 meetings to get the design of the appropriate learning model. Based on the process that has been done got a design of learning model which is a combination of learning component in two schools, but gave new thing in the form of psychomotor aspect which is raised to apply Islamic values. Once implemented, there are changes in the behavior of learners in their daily life and the increased aspects of cognitive, affective and psychomot learners in the subject matter.

Keyword: Design of Learning, Model of Simulation, Islamic Values
\end{abstract}

\section{Abstrak}

Proses pembelajaran tari kini dihindari beberapa sekolah, karena tujuan pembelajaran yang tidak dipahami secara mendalam oleh semua pihak. Namun terdapat beberapa sekolah di Kabupaten Tasikmalaya yang mengajarkan seni tari di dalam proses pembelajarannya bahkan dengan menerapkan nilai-nilai Islami. Nilai-nilai Islami merupakan nilai yang penting ditanamkan pada diri peserta didik untuk membentuk karakter yang baik. Dengan menganalisis dua sekolah yang melakukan pembelajaran tari untuk menerapkan nilai-nilai Islami peneliti merancang desain model pembelajaran pengembangan simulasi yang dilakukan di sekolah lainnya di Kabupaten Tasikmalaya. Nilai-nilai Islami yang diterapkan berasal dari sifat-sifat Nabi Muhammad SAW, yakni sidiq, tabligh, amanah dan fatonah. Peneliti menggunakan stimulus cerita tokoh dan pahlawan Islam untuk mengubah ide cerita menjadi gerak sedangkan ide geraknya mengembangkan gerak Ibing Pencak. Teori-teori yang digunakan dalam penelitian ini yakni teori koneksionis, teori perkembangan remaja, teori pendidikan dan lain-lain. Penelitian ini menggunakan metode Design Based Research dengan pendekatan kualitatif. Penelitian ini dilakukan secara bertahap dengan pengulangan siklus. Terdapat 4 siklus dengan 6 kali pertemuan untuk mendapatkan desain model pembelajaran yang sesuai. Berdasarkan proses yang telah dilakukan didapatkan sebuah rancangan desain model pembelajaran yang merupakan gabungan dari komponen pembelajaran di dua sekolah, namun melahirkan hal baru berupa aspek psikomotor yang dimunculkan untuk menerapkan nilai-nilai Islami. Setelah diimplementasikan, terdapat perubahan perilaku peserta didik dalam kesehariannya serta meningkatnya aspek kognitif, afektif dan psikomot peserta didik dalam materi pelajaran.

Kata Kunci: Desain Model Pembelajaran, Model simulasi, Nilai-nilai Islami

\section{A. PENDAHULUAN}

Pendidikan merupakan sebuah lembaga yang dilakukan dengan sadar dan terencana dengan tujuan untuk memanusiakan manusia. Pendidikan kini dianggap penting oleh masyarakat, sehingga diharapkan pendidikan dapat tersebar secara merata di seluruh pelosok dengan kualitas yang baik. Pendidikan merupakan hal yang penting untuk dilaksanakan, Undang-undang (UU) No. 20 Tahun 2003 tentang Sistem Pendidikan Nasional (Sisdiknas) menjelaskan, yakni:

Pendidikan adalah usaha sadar dan terencana untuk mewujudkan suasana belajar dan proses pembelajaran agar peserta secara aktif mengembangkan potensi dirinya untuk memiliki kekuatan spiritual keagamaan, pengendalian diri, kepribadian, kecerdasan, akhlak, serta keterampilan yang diperlukan dirinya, masyarakat, bangsa dan negara (Cahyo, 2013, hlm. 18)

Hal di atas juga ditegaskan oleh Mulyasa (2004, hlm. 21) yakni "Tujuan pendidikan nasional bertujuan membentuk manusia yang beriman dan bertaqwa kepada Tuhan Yang Maha Esa, beretika (Beradab dan berwawasan budaya bangsa Indonesia), memiliki nalar (maju, cakap, cerdas, kreatif, 
inovatif dan bertanggung jawab), berkemampuan komunikasi sosial (tertib dan sadar hukum, kooperatif dan kompetitif, demokratis), dan berbadan sehat sehingga menjadi manusia mandiri”.

Mata pelajaran seni budaya pokok bahasan seni tari menempatkan tari sebagai sebuah media dalam pembelajaran agar peserta didik mendapatkan pengetahuan mengenai teks dan konteks tari serta perubahan perilaku peserta didik setelah mengikuti pembelajaran tari. Hal tersebut dinamakan Tari Pendidikan. Juju Masunah dan Tati Narawati (2003, hlm. 246) juga mengungkapkan bahwa "Tari Pendidikan, tari atau gerak merupakan media atau alat ungkap yang digunakan untuk mengembangkan sikap, pola pikir, dan motorik anak menuju arah kedewasaannya". Dari kutipan di atas, terlihat jelas bahwa pelajaran seni tari bukan sekedar hanya bergerak, menari dengan diiringi musik tetapi dari pelajaran tari kita bisa mengambil nilai-nilai baik di dalamnya untuk mengembangkan sikap dan pemikiran peserta didik agar menuju arah kedewasaannya. Tabroni (2008: hlm. 13) mengungkapkan bahwa "perkembangan pemikiran tentang pendidikan yang menjadi dasar terbentuknya pendidikan berkualitas, perlu terus digalakan agar pendidikan dapat mengemban fungsi dan perannya secara maksimal dalam membangun manusia berkualitas dan untuk memenuhi harapan keluarga, umat, dan bangsa". Dengan demikian, seorang pendidik harus bisa mengemas pembelajaran seni tari agar kebermanfaatan dalam sebuah tarian bisa diinternalisasikan dalam dunia pendidikan.

Tari Pendidikan dan pendidikan tari, walaupun istilah tersebut memiliki kesamaan kata hanya penempatannya saja yang berbeda namun memiliki arti yang jauh berbeda. Pendidikan tari merupakan sebuah media atau alat dari guru agar peserta didik mampu menari dengan benar. Hasil dalam pendidikan tari tidak diharapkan adanya perubahan perilaku menjadi lebih baik, melainkan pendidikan tari lebih menekankan pada hasil agar peserta didik mampu menari. Hal tersebut diungkapkan oleh Juju Masunah dan Tati Narawati (2003, hlm. 246) bahwa "yang diutamakan dalam pendidikan tari adalah produknya dimana siswa mampu menguasai tari, baik secara teks maupun konteksnya”. Dari ungkapan di atas, tentu terlihat jelas perbedaan tujuan dari Tari Pendidikan dengan pendidikan tari. Jika Tari Pendidikan menekankan pada penilaian proses, sedangkan pendidikan tari menekankan pada penilaian hasil. Kemudian, Tari Pendidikan bertujuan untuk mengubah sikap dan pola pikir peserta didik agar menuju kedewasaannya selain itu pendidian tari bertujuan untuk mencetak anak sebagai seniman/penari yang bagus. Mengubah sikap dan pola pikir peserta didik melalui tari pendidikan, sehingga menghasilkan karakter yang baik.

"Character determines someone's
private thoughts and someone's
actions done. Good character is the
inward motivation to do what is right,
according to the highest standard of
behaviour, in every situation" (Hill
dalam Christina, 2005, hlm. 84).

Pendidikan karakter mengajarkan kebiasaan cara berpikir dan perilaku yang membantu individu untuk hidup dan bekerja bersama sebagai keluarga, masyarakat, dan bernegara dan membantu mereka untuk membuat keputusan yang dapat dipertanggungjawabkan (Christina,2005, hlm.84). dari ungkapan Christina di atas menjelaskan bahwa pendidikan karakter, dapat membangun dan memperkuat sikapsikap peserta didik dalam bekerja keras, bertanggung jawab, kerja sama dan lain-lain.

Pemahaman mengenai Tari Pendidikan nyatanya belum dipahami benar oleh masyarakat pada umumnya bahkan beberapa guru sekalipun, mereka berpendapat bahwa pembelajaran tari mengutamakan hasil agar anak mampu menari dengan baik. Masyarakat yang memiliki pemahaman demikian dikarenakan antara satu orang dengan orang lain disekitarnya atau dalam sau daerah memiliki pemahaman yang hampir sama, sehingga untuk mengubah pemahaman masyarakat perlu adanya unsur yang sesuai dengan adat istiadat masyarakat tersebut. Koentjaraningrat (2011, hlm. 122) mengungkapkan bahwa Masyarakat adalah kesatuan hidup manusia yang berinteraksi sesuai dengan sistem adat istiadat tertentu yang sifatnya berkesinambungan. Mereka berpikir bahwa dalam pembelajaran tari, guru mengajarkan sebuah tarian full kepada peserta didik. Kemudian, peserta didik mengikuti, sehingga peserta didik menjadi seorang penari yang bagus. Sebenarnya, Tari 
Pendidikan bukanlah seperti pendapat di atas. Tari Pendidikan benar-benar menekankan pada proses, sehingga melalui media tari diharapkan peserta didik mendapatkan pembelajaran yang mengubah sikap atau karakter mereka menjadi lebih baik, juga menambah pengetahuan dan keterampilan peserta didik. Hal tersebut didapatkan dari nilai-nilai yang terkandung dalam tarian yang akan disampaikan. Leluhur bukan hanya mewariskan sebuah kebudayaan atau kesenian (yang di dalamnya terdapat tarian) saja kepada kita, melainkan terdapat banyak nilai-nilai luhur yang terdapat di dalamnya. Hal tersebut dapat kita refleksikan melaui sebuah pendidikan, yaitu pendidikan nilai. Mardimadja dalam Zaim Elmubarok (2009, hlm. 12) mengungkapkan bahwa "Pendidikan nilai sebagai bantuan terhadap peserta didik agar menyadari dan mengalami nilai-nilai serta menempatkannya secara integral dalam keseluruhan hidupnya". Dari ungkapan di atas, dapat dipahami bahwa nilai-nilai baik yang disampaikan guru kepada peserta didik dalam proses pembelajaran agar peserta didik dapat merasakan sendiri nilai-nilai tersebut yang kemudian diinternalisasikan dalam kehidupan sehari-hari mereka. Pada akhirnya, peserta didik akan menjadi manusia yang lebih baik, karena terbiasa menerapkan nilai-nilai baik di dalam kehidupan sehari-harinya melalui Tari Pendidikan.

Nilai-nilai yang akan diimplementasikan berasal dari sifat-sifat yang dimiliki oleh utusan ALLOH SWT yakni Nabi Muhammad SAW. Nilai-nilai karakter yang esensial (core essential character values), yang ada pada diri Nabi sangat dikenal dengan empat akhlaknya, yang sering dibuat akronim sebagai sifat, yaitu: (1) Siddiq, (2) Tabligh, (3) Amanah, dan (4) Fathonah (STAF) (Mulyasa: 2011, hlm. 16). Data diambil dan dianalisis dari peserta didik, kepala sekolah dan pihak-pihak lain yang berkompeten lainya agar pengembangan design yang baru lebih baik lagi. Syafiec I Ma"earif (1991: hlm. 15) mengungkapkan desain pendidikan selayaknya dipersiapkan secara matang sehingga hasil yang dicapai pun memuaskan. Maka peneliti mengambil judul penelitian Desain Model Pembelajaran Simulasi Untuk Menerapkan Nilai-nilai Islami di SMPT Manahijul Huda Tasikmalaya.
Tujuan penelitian ini untuk mendeskripsikan analisis, rancangan dan penerapan Pembelajaran Tari untuk Menerapkan Nilai-nilai Islami Di SMPN 2 Ciawi dan SMPN 1 Kadipaten Kabupaten Tasikmalaya. Adapun mengenai metode penelitian., penelitian ini akan menggunakan rancangan penelitian Design Based research (DBR). Menurut Plomp (2007, hlm. 13) Design Based research adalah sebagai berikut.

Suatu kajian sistematis tentang merancang, mengembangkan dan mengevaluasi intervensi pendidikan seperti program, strategi dan bahan pembelajaran, produk dan sistem sebagai solusi untuk memecahkan masalah yang kompleks dalam praktik pendidikan, yang bertujuan untuk memajukan pengetahuan kita tentang karakteristik dari intervensi-intervensi tersebut serta proses perancangan dan pengembangannya.

Dari ungkapan Plomp di atas, dapat dipahami bahwa Design Based research (DBR) bertujuan untuk merancang dan mengembangkan komponen pembelajaran, baik itu strategi pembelajaran, bahan pembelajaran maupun produk dan sistem. Komponen-komponen tersebut dirancang lalu dikembangkan agar masalah yang dihadapi di dunia pendidikan dapat dipecahkan, sehingga dunia pendidikan lebih maju. Hasil akhir dari metode Design Based research (DBR) ini merupakan merancang sebuah design model pembelajaran tari untuk menerapkan nilai-nilai Islami. Benny A. Pribadi (2009, hlm. 86) mengungkapkan "Model desain sistem pembelajaran biasanya menggambarkan langkah-langkah atau prosedur yang perlu ditempuh untuk menciptakan aktivitas pembelajaran yang efektif, efisien dan menarik". Maka hasil dari penelitian ini merupakan langkah-langkah atau prosedur pembelajaran yang dirancang agar proses pembelajaran menjadi menarik dan efektif.

B. HASIL DAN PEMBAHASAN

1. Analisis Pembelajaran Tari untuk Menerapkan Nilai-nilai Islami Di SMPN 2 Ciawi dan SMPN 1 Kadipaten Kabupaten Tasikmalaya 
Dari penjabaran setiap pertemuan dalam proses pembelajaran di SMPN 2 Ciawi dan SMPN 1 Kadipaten yang telah peneliti paparkan pada bagian temuan di atas, peneliti menganalisis bahwa SMPN 2 Ciawi dan SMPN 1 Kadipaten menggunakan model yang berbeda serta komponen pembelajaran yang digunakannya pun berbeda pula.

SMPN 1 Kadipaten memiliki tujuan pembelajarannya untuk menerapkan nilai religius, bersahaja dan kebersamaan melalui pembelajaran tari (Kesenian Marawis) dengan metode pembelajarannya menggunakan mix method yaitu metode ceramah, metode tanya jawab, metode diskusi dan metode demonstrasi, menggunakan media audio dan audio visual sedangkan evaluasi pembelajarannya dengan cara evaluasi kualitatif yang dinyatakan dengan ungkapan sangat baik, baik, cukup, kurang dan sangat kurang. Peran guru di SMPN 1 Kadipaten banyak memotivasi siswa untuk mencintai budayanya dan mengangkat kesenian lokal. Materi atau bahan ajar yang digunakan tidak terlalu mendalam membahas mengenai kesenian Marawis. Namun, strategi pemeblajaran yang digunakan di SMPN 1 Kadipaten ini yakni Strategi Ekspositori, yaitu strategi dengan guru yang memiliki peran lebih banyak dibanding peserta didik. Hal tersebut menyebabkan anak kurang kreatif. Penyampaian guru mengenai kesenian Marawis yang digunakan sebagai bahan ajar pun kurang mendalam serta pembatasan gerak yang menyebabkan peserta didik kurang kreatif. Dari analisis komponen pembelajaran di SMPN 1 Kadipaten terdepat kekuatan dalam poin tujuan, metode, media, dan evaluasi. Namun, dalam poin startegi pembelajaran dan penyampaian guru memiliki kelemahan sehingga perlu diperkuat lagi agar lebih sempurna dan hasil pembelajaran akan memuaskan.

Model pembelajaran yang digunakan memiliki karakteristik yang sama dengan model direct instruction. Karakteristik tersebut terlihat dengan diawali penjelasan guru mengenai suatu kosep atau materi baru kepada peserta didik, dilanjutkan meminta siswa menguji pemahaman mereka dengan melakukan praktik di bawahan bimbingan guru (controlled practice) dan mendorong peserta didik untuk meneruskan praktik di bawah bimbingan guru (guided practice) (Joyce dan Weil, 2009: hlm. 423). Penjelasan guru terlihat ketika Dadang Cahya, A.Md memberikan penjelasan mengenai unsurunsur tari dan gerak-gerak dasar tangan dan kaki yang beliau tunjukkan di depan kelas. Kemudian meminta siswa untuk mengikuti apa yang telah ditunjukkan, sehingga guru tersebut dapat menguji pemahaman peserta didik mengenai materi yang disamapikan. Setelah itu, guru meminta peserta didik melanjutkan praktik gerak dasar tangan dan kaki bersama teman sekelompoknya namun tetap diawasi oleh guru. Sehingga, SMPN 1 Kadipaten di analisis menggunakan model direct instruction.

Sekolah lainnya, yakni SMPN 2 Ciawi memiliki tujuan pembelajaran untuk menerapkan nilai religius, gigih dan pantang menyerah melalui pembelajaran tari. Materi atau bahan ajar yang digunakan selain dari buku paket dari pemerintah juga membahas cerita kepahlawanan Islam dengan metode pembelajarannya menggunakan mix method yaitu metode ceramah, metode tanya jawab, metode diskusi, metode demonstrasi, metode resitasi, dan metode eksperimental dan menggunakan media audio, audio visual, dan interaktif.. Teknik evaluasi pembelajarannya dengan cara evaluasi kualitatif yang dinyatakan dengan ungkapan sangat baik, baik, cukup, kurang dan sangat kurang. Namun, guru terlalu memberikan kebebasan dalam menciptakan gerak, sehingga gerak yang dihasilkan kurang bermakna, sehingga perlu perbaikin pada pembatasan gerak bagi peserta didik dalam bereksplorasi.

Model pembelajaran yang di gunakan di SMPN 2 Ciawi ini mengarah kepada model simulasi. Yakni membuat simulasi dari sebuah kejadian atau peristiwa yang telah dirancang dalam sebuah skenario. Pada proses pembelajaran di SMPN 2 Ciawi terlihat jelas bahwa peserta didik membuat simulasi dari cerita seorang pahlawan Islam yakni KH. Zainal Mustofa dalam membela Islam, kemudain peserta didik membuat skenarionya untuk dituangkan dalam bentuk gerak. Dari analisis di atas, peneliti menganalisi SMPN 2 Ciawi menggunakan model simulasi.

Dari analisis kedua sekolah tersebut, yakni SMPN 1 Kadipaten dan SMPN 2 Ciawi memiliki kekuatan dan kelemahan dalam beberapa poin komponen pembelajaran serta dalam langkah-langkah pembelajarannya, sehingga peneliti akan merancancang komponen pembelajaran 
untuk menerapkan nilai-nilai Islami di SMPT Manahijul Huda. Model yang akan dikembangkan yakni model simulasi yang digunakan di SMPN 2 Ciawi, karena peneliti melihat peluang yang besar untuk menghasilkan tujuan yang diharapkan dalam menerapkan nilai-nilai Islami.

\section{Rancangan Desain Model Pembelajaran Tari untuk Menerapkan Nilai-nilai Islami}

Dari nilai-nilai yang di terapkan di SMPN 2 Ciawi yakni religius, gigih dan pantang menyerah serta SMPN 1 Kadipaten yakni religius, bersahaja dan kebersamaan, nilai-nilai tersebut sudah terangkum pada sifat-sifat Nabi Muhammad SAW yang patut di tauladani oleh ummatnya. Sifat-sifat Nabi Muhammad SAW yang patut ditauladani tersebut yakni sidiq, tabligh, amanah dan fatonah. Dari setiap sifat tersebut memiliki indikator yang mencakup semua nilai-nilai baik yang ditetapkan pemerintah dan para ahli. Menurut Abdul Majid dan Dian Andayani (2012) Sumber nilai yang berlaku dalam pranata kehidupan manusia dapat digolongkan menjadi dua macam yakni nilai Ilahiyah dan nilai Insyaniyah yang memiliki turunan nilai dari Iman, Ihsan dan Islam. Berikut merupakan indikator dari sifat Nabi Muhammad SAW yang dikemukakan oleh Hermansyah (2015) yang juga berkaitan dengan nilai Ilahiyah dan nilai Insyaniyah .

Tabel 1

Indikator nilai-nilai Islami

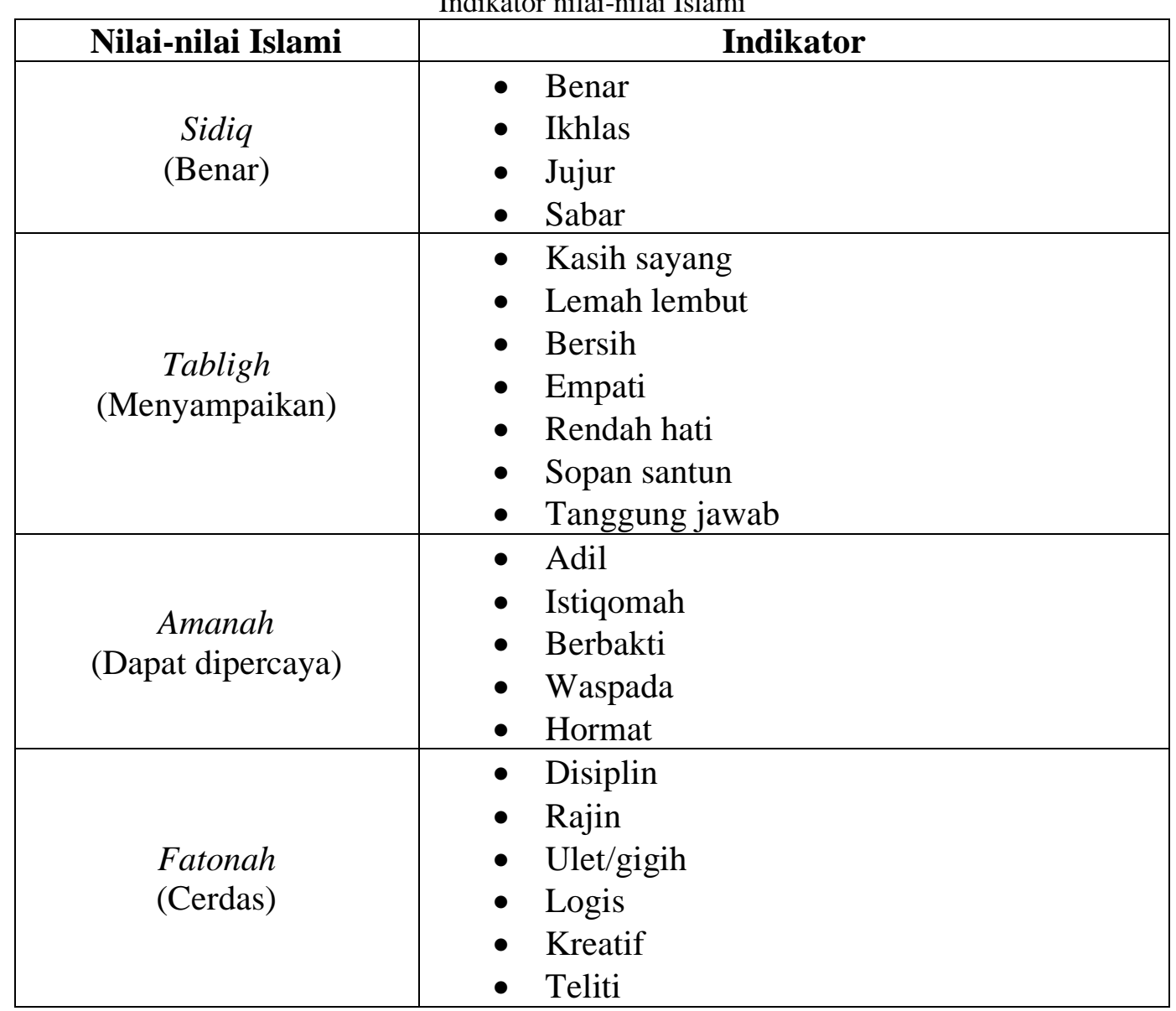

Dari tabel di atas peneliti menggunakan beberapa nilai yang akan diimplementasikan dalam proses pembelajaran kepada peserta didik. Peneliti rasa sangatlah tepat jika nilai-nilai yang diterapkan kepada peserta didik bersumber dari sosok yang menjadi tauladan dan utusan Alloh SWT dalam menyebarkan agama Islam di muka bumi. Nilai-nilai karakter yang diungkapkan oleh Syaikh Al Izz dalam
Pupuh Faturrohman (2013), Ratna Megawangi, Ari Ginanjar dan lain-lain sudah tercantum dalam nilai-nilai yang terdapat dalam indikator nilai sidiq, tabligh, amanah, dan fatonah. Pemilihan nilai yang akan diimplementasikan tersebut berdasarkan terhadap karakter yang harus dimiliki oleh seorang pahlawan atau seorang tokoh Islam yang ceritanya digunakan oleh peneliti sebagai stimulus untuk pembelajaran tari 
yang dari cerita tersebut akan dituangkan ke dalam bentuk gerak. Berikut ini peneliti paparkan nilai-nilai Islami tersebut beserta indikator nilai yang akan diterapkan kepada peserta didik melalui pembelajaran tari.

Tabel 2

Indikator nilai-nilai Islami yang akan diimplementasikan

\begin{tabular}{|c|l|}
\hline Nilai-nilai Islami & \multicolumn{1}{|c|}{ Indikator } \\
\hline Sidiq & $\checkmark$ Ikhlas \\
(Benar) & $\checkmark$ Jujur \\
\hline Tabligh & $\checkmark$ Sopan santun \\
(Menyampaikan) & $\checkmark$ Tanggung jawab \\
\hline Amanah & $\checkmark$ Adil \\
(Dapat dipercaya) & $\checkmark$ Hormat \\
\hline Fatonah & $\checkmark$ Ulet/gigih \\
(Cerdas) & $\checkmark$ Disiplin \\
\hline
\end{tabular}

Setelah peneliti mendapatkan nilainilai Islami yang akan diimplementasikan kepada peserta didik maka, langkah selanjutnya peneliti membuat rancangan komponen pembelajaran. Juju Masunah (2003) menyatakan bahwa pendidkan tari bertujuan untuk mengubah karakter peserta didik, salah satunya adalah core essential values dari Rasulloh SAW di atas. Dalam perancangannya tentu saja peneliti mengalami beberapa kali revisi guna menyempurnakan desain model pembelajaran yang peneliti rancang. Hal tersebut juga diungkapkan oleh Trianto (2009, hlm. 192) bahwa “...secara umum tiap-tiap langkah pengembangan perangkat pembelajaran berhubungan secara langsung dengan aktivitas revisi". Hal pertama yang peneliti lakukan dalam membuar desain yakni membuat tujuan pembelajaran. Menurut Ibrahim (2003) dalam Trianto (2009, hlm. 192) bahwa "kurikulum yang berlaku secara nasional di Indonesia berorientasi pada tujuan, maka seyogyanya proses pengembangan itu dimulai dari tujuan". Setelah itu peneliti merancang materi, metode, evaluasi dan media serta tahapan dan langkah-langkah pembelajaran.

\section{DESAIN PENGEMBANGAN MODEL}

\section{SIMULASI}

Dalam merancang desain pembelajaran, di dalamnya harus terdapat komponen pembelajaran. Toto Ruhimat dkk (2009) mengungkapkan bahwa komponen pembelajaran terdiri dari tujuan, bahan, media, strategi dan evaluasi. Berikut adalah komponen pembelajaran tari untuk menanamkan nilai-nilai Islami.

$\checkmark$ Tujuan pembelajarannya untuk menerapkan nilai-nilai Islmai melalui pembelajaran tari dengan cerita tokoh Islami, yaitu sidiq, tabligh, amanah, dan fatonah dengan indikator nilai yang telah ditentukan.

$\checkmark$ Materi atau bahan ajar yang digunakan yaitu cerita kepahlawanan Islam yang mendunia agar lebih memotivasi siswa. Zaim Elmubarok mengungkapkan bahwa.

Dikarenakan misi pendidikan nilai adalah memuncakan domain afeksi dalam rangka memanusiakan manusia (N. Driyarkara, 1991), maka cerita dan kisah yang ditampilkan mewakili kisikisi tentang kemanusian dan menjadi manusia. Diantara kisi-kisi itu adalah: menolong sesama, empati, kejujuran, saling berbagi, kesetiaan, kesejatian, hikmah (pelajaran berharga). Kegigihan dan keuletan, kebermanfaatan, toleransi, menghargai sesama, kesabaran, membalas kejelekan denga kebaikan, mengedepankan kebaikan dari keburukan, bahaya kejelekan dan kualitas amal kebaikan".

Dari ungkapan Zaim Elmubarok di atas, melalui cerita pahlawan atau tokoh Islam yang inspiratif kaya akan pesan dan nilai di dalamnya, sehingga setelah mendengarkan cerita peserta didik mendapatkan nilai-nilai baik atau karakter yang harus mereka implementasikan dalam kehidupan nyata. Yusuf (2009) menyatakan bahwa pada dasarnya peserta didik usia remaja memiliki ketertarikan terhadap banyak hal.

Setelah memberikan stimulus lewat cerita pahlawan atau tokoh Islam, peserta didik 
memahamai bahwa karakter yang harus mereka miliki yang kemudian akan diimplementasikan dalam kehidupan seharihari. Setelah itu, dari cerita pahlawan atau tokoh Islam di atas peserta didik membuat ragam gerak yang sesuai dengan karakter seorang pahlawan atau tokoh Islam. Stimulus gerak yang diberikan sebagai dasar kepada peserta didik yakni dari ibing pencak. Ibing pencak adalah gerak dasar beladiri yang disajikan dalam bentuk tarian atau gerak kembangnya beladiri Pencak Silat (Yuliawan dan Isus 2010, hlm. 7). Selain itu Notosoejitno (1997) mengungkapkan Dalam kaitan denga istilah "pencak silat seni" kata seni berarti indah dan pencak silat seni berarti pencak silat indah. Sedangkan dalam konteks istilah "seni pencak silat", kata seni berarti kecakapan keterampilan dan kemahiran teknis dan taktis yang tinggi dalam melakuakan pencak silat.

Ibing pencak sendiri dalam penyajiannya diiringi alat musik tradisional kendang pencak. Pemain ibing pencak dapat menggunakan senjata maupun tidak, sesuai dengan kebutuhan, sehingga tujuannya pun berbeda dengan beladiri pencak silat yakni untuk keindahan atau estetika saja. Mulyana (2014) menyatakan perbedaan pencak silat seni dan pencak silat beladiri terletak pada nilai, orientasi, papakem dan ukuran yang diterapkan dalam proses pelaksanaannya. Pelaksanaan pencak silat beladiri bernilai teknis, orientasinya efektif, praktis, taktis, dan pragmatis. Lain halnya dengan pencak silat seni bernilai estetis yang orientasinya pada keindahan dalam arti luas, meliputi keselarasan dan keserasian. Johansyah Lubis dan Hendro Wardoyo (2014) mengungkapkan terdapat 4 aspek utama dalam pengembangan bela diri pencak silat, yaitu :

1. Aspek akhlak/rohani (mental spiritual)

a. Bertaqwa epada Tuhan yang maha esa, dan berbudi pekerti luhur.

b. Tenggang rasa, percaya diri sendiri dan berdisiplin.

c. Cinta bangsa dan tanah air.

d. Persaudaraan, pengendalian diri dan tanggung jawab sosial
2. Aspek bela diri

3. Aspek seni budaya: budaya dan pemainan "seni" pencak silat ialah salah satu aspek yang sangat penting. Istilah pencak pada umumnya menggambarkan bentuk seni tarian pencak silat, dengan musik dan busana tradisional

4. Aspek olahraga

Dalam praktik pembelajaran peneliti tidak mengharuskan peserta didik menggunakan senjata sebagai properti. Ibing pencak dipilih karena dalam berperang tentu saja seorang pahlawan atau tokoh Islam perlu memiliki cara beladiri, sehingga ibing pencak sesuai dengan topik pembelajaran. Gerak-gerak ibing pencak yang dijadikan contoh dalam proses pembelajaran tari yaitu sikap, pasang, besot, ayun muka dan ayun nutup, giles kanan, langkah maju giles tangan, sikut kanan serta bandul. Selain itu, dalam gerakan tersebut terkandung makna dan nilai-nilai Islami. Penelitian memfokuskan pada proses pengembangan gerak ibing pencak yang dikreasikan oleh peserta didik sebagai subjek penelitian. Pembelajaran tari merupakan pembelajaran yang multidimensional karena menyangkut potensi dalam diri peserta didik, multikultural dan multilingual karena mencoba menyampaikan cerita dalam bentuk gerak. Stimuls cerita dan stimulus gerak penting disampaikan karena menurut Teori Koneksionis Edward L Thorndike bahwa stimulus dalam proses pembelajaran penting untuk mendapatkan respon dari peserta didik sehingga tujuan pembelajaran dapat tercapai.

$\checkmark$ Metode pembelajarannya menggunakan mix method yaitu metode ceramah, metode tanya jawab, metode diskusi, metode demonstrasi, metode resitasi, dan metode eksperimental.

$\checkmark$ Menggunakan media audio, audio visual, dan interaktif.

$\checkmark$ Evaluasi pembelajarannya dengan cara evaluasi kualitatif yang dinyatakan dengan ungkapan baik, cukup, dan kurang. Serta evaluasi menggunakan teknik non tes melalui pengamatan, wawancara, hasil karya dan skala sikap. 
Tabel 3 Contoh Format Penilaian

\begin{tabular}{|c|c|c|c|c|c|c|c|c|c|c|c|c|c|}
\hline \multirow{2}{*}{ NO } & \multirow{2}{*}{ NAMA } & \multicolumn{3}{|c|}{ SIDIQ } & \multicolumn{3}{c|}{ AMANA } & \multicolumn{3}{|c|}{ TABLIG } & \multicolumn{3}{|c|}{ FATONAH } \\
\cline { 3 - 12 } & & B & C & K & B & C & K & B & C & K & B & C & K \\
\hline 1 & & & & & & & & & & & & & \\
\hline 2 & & & & & & & & & & & & & \\
\hline 3 & & & & & & & & & & & & & \\
\hline dst & & & & & & & & & & & & & \\
\hline
\end{tabular}

Berikut adalah desain pengembangan model pembelajaran yang peneliti rancang untuk menerapkan pembelajaran tari untuk menerapkan nilai-nilai Islami. Model simulasi dipilih untuk dikembangkan karena merupakan salah satu rumpun Model perubahan tingkah laku menurut Joyce dan Weil (2009) yang menekankan pada upaya untuk mengubah perilaku yang tampak dari para siswa, sehingga sesuai dengan tujuan penelitian ini untuk menanamlan nilai-nilai Islami pada peserta didik agar terbangun sikap sidiq, tabligh, amanah dan fatonah seperti Rasululloh SAW. Berikut rancangan model pembelajaran pengembangan dari Simulasi untuk menanamkan nilai-nilai Islami dengan stimulus cerita tokoh Islam dan gerak Ibing pencak ::

1. Tahap Orientasi

- Guru menyajikan nilai-nilai Islami yang akan diimplementasikan yang berasal dari sikap Rasulullah SAW yaitu Sidiq, Tabligh, Amanah dan Fatonah beserta indikator nilai di dalamnya..

- Guru menyajikan topik mengenai cerita kepahlawan dan tokoh Islam yang inspiratif.

- Guru menjelaskan gerak khas dari tari yang bertema kepahlawanan yaitu ibing pencak dengan makna dan nilainilai Islam yang terkandung di dalamnya.

- Guru menjelaskan bahwa siswa akan membuat simulasi dari materi yang telah diberikan dalam bentuk tarian

2. Tahap Latihan Partisipasi

- Guru meminta siswa membuat skenario (aturan, peran dan prosedur)

- Guru menugaskan peran simulasi kepada siswa

- Guru menugaskan siswa untuk membuat gerak pengembangan dari gerak dari ibing pencak dan membuat gerak yang bertema kepahlawanan untuk menanamkan nilai-nilai Islami.

- Siswa mengeksplor gerak

- Siswa memaknai dari setiap gerak yang dibuat

3. Tahap Pelaksanaan Simulasi

- Siswa memimpin aktifitas simulasi

- Guru mengawasi jalannya simulasi

- Siswa mendapatkan umpan balik dan evaluasi (mengenai penampilan)

- Siswa merancang sebuah karya dari gerak yang telah dibuat

- Siswa melanjutkan simulasi

4. Tahap Wawancara

- Siswa menampilkan hasil karyanya

- Guru dann siswa menilai dan menyimpulkan kejadian dan persepsi dari hasil karya siswa

- Siswa menyimpulkan kesulitan dan pandangan-pandangannya

- Guru dan siswa menganalisis proses

- Guru dan siswa membandingkan aktivitas simulasi dengan dunia nyata

- Siswa menghubungkan aktifitas simulasi dengan materi pelajaran

Dari rancangan pengembangan model di atas, peneliti menambahkan langkah-langkah pembelajaran yang menyangkut aspek psikomotor agar keterampilan peserta didik lebih muncul. Peneliti juga mengubah posisi guru sebagai center tetapi menjadikan peserta didik sebagai center dalam proses pembelajaran, sehingga peserta didik dapat berperan aktif dalam proses pembelajaran. Huitt dalam Aunurrahman (2011, hlm. 143) mengaitkan bahwa

"Meskipun keterlibatan siswa dalam proses pembelajaran di kelas merupakan hal yang sangat penting, akan tetapi guru harus tetap dapat 
mengontrol aktivitas perilaku siswa di kelas (classroom management activities), mencermati perbedaanperbedaan antar siswa serta karakteristik masing-masing individu".

Peran guru lebih menjadi fasilitator dan motivator bagi peserta didik. Selanjutnya peserta didik akan menerapkan rancangan pengembangan model ini kepada SMPT Manahijul Huda. Sesungguhnya setiap individu pasti memiliki rasa estetika, Yuliawan Kasmahidayat (2010) menyatakan bahwa keindahan adalah bawaan alami yang dianugerahkan Alloh SWT, sehingga setiap peserta didik dapat mengembangakn gerak untuk membuat sebuah karya dengan indah.

\section{Penerapan Rancangan Desain Model Pembelajaran Tari untuk Menerapkan Nilai-nilai Islami Di SMPT Manahijul huda Kabupaten Tasikmalaya}

Pengetahuan, keterampilan, dan sikap dari kondisi belajar, merupakan tujuan yang ingin dicapai baik yang diprogram oleh guru (inilah yang sebaiknya) maupun yang tidak diprogram oleh guru. Maka peneliti merancang langkah-langkah pembelajaran, agar tujuan yang diharapkan dapat tercapai. Berikut adalah penjelasan mengenai langkah-langkah pembelajaran yang telah dilakukan.

Sintaks desain pembelajaran tari berbasis nilai-nilai Islami

Tabel 4

Hasil Metode DBR Pada pengembangan model simulasi.

\begin{tabular}{|c|c|c|}
\hline TAHAP & PERTEMUAN & PERLAKUAN GURU \\
\hline & PERTEMUAN 1 & $\begin{array}{l}\text { - Menyajikan nilai-nilai Islami yang akan } \\
\text { diterapkan yakni sidiq, tabligh amanah } \\
\text { dan fatonah serta topik mengenai cerita } \\
\text { kepahlawan Islam. } \\
\text { - Menjelaskan gerak khas dari ibing pencak, } \\
\text { dan memeperagakannya diserta makna } \\
\text { dan nilai yang terkandung di dalamnya. } \\
\text { - Menjelaskan bahwa siswa akan membuat } \\
\text { simulasi berbentuk tarian dengan tema } \\
\text { kepahlawanan dari cerita tokoh Islam. }\end{array}$ \\
\hline TAHAP 1 & PERTEMUAN 2 & $\begin{array}{l}\text { - Guru menyajikan nilai-nilai Islami yang } \\
\text { akan diimplementasikan yang berasal dari } \\
\text { sikap Rasulullah SAW yaitu Sidiq, } \\
\text { Tabligh, Amanah dan Fatonah.. } \\
\text { - Guru menyajikan topik mengenai cerita } \\
\text { kepahlawan dan tokoh Islam yang } \\
\text { inspiratif. } \\
\text { - Guru menjelaskan gerak khas dari tari } \\
\text { yang bertema kepahlawanan yaitu ibing } \\
\text { pencak dengan makna dan nilai-nilai } \\
\text { Islam yang terkandung di dalamnya. } \\
\text { Guru menjelaskan bahwa siswa akan } \\
\text { membuat simulasi dari materi yang telah } \\
\text { diberikan dalam bentuk tarian }\end{array}$ \\
\hline TAHAP 2 & PERTEMUAN 3 & $\begin{array}{l}\text { - Menugaskan peran simulasi kepada siswa } \\
\text { dari cerita tokoh Islam. } \\
\text { - Guru menugaskan siswa untuk membuat } \\
\text { gerak pengembangan dari ibing pencak } \\
\text { yang telah dipelajari sebelumnya. } \\
\text { - Meminta siswa memaknai dari setiap } \\
\text { gerak yang dibuat. } \\
\text { - Meminta siswa melaksanakan praktik } \\
\text { dalam jangka waktu yang singkat }\end{array}$ \\
\hline
\end{tabular}




\begin{tabular}{|l|l|l|}
\hline TAHAP & PERTEMUAN & \multicolumn{1}{c|}{ PERLAKUAN GURU } \\
\hline & & $\begin{array}{l}\text { - Guru meminta siswa membuat skenario } \\
\text { (aturan, peran dan prosedur) } \\
\text { - }\end{array}$ \\
& & Guru menugaskan peran simulasi kepada \\
siswa & Guru menugaskan siswa untuk membuat \\
gerak pengembangan dari gerak dari ibing \\
pencak dan membuat gerak yang bertema \\
kepahlawanan untuk menanamkan nilai- \\
nilai Islami. \\
PERTEMUAN 4
\end{tabular}

Sintaks di atas disusun berdasarkan proses pembelajaran yang telah berlangsung. Pada sintaks di atas, terdapat 4 tahap pembelajaran dari pengembangan model simulasi. Dari keempat tahap tersebut terjadi pengulangan, karena hasil penilaian nilainilai Islami dari proses pembelajaran tari tidak mencapai tujuan yang diharapkan. Setelah mengalami pengulangan grafik menunjukan bahwa peserta didik menunjukan perkembangan, baik secara pemahaman maupun perilaku. Sehingga desain pembelajaran dikatakan berhasil. Desain pembelajaran tersebut merupakan pengembangan dari model simulasi Carl Smith dan Mery Smith, yang peneliti sesuaikan dengan pembelajaran tari, kebutuhan dan kemampuan peserta didik. Berikut adalah hasil akhir desain pembelajaran yang telah mengalami revisi.

Tabel 5

Desain Pengembangan Model

\begin{tabular}{|c|c|}
\hline TAHAP & PERLAKUAN GURU \\
\hline TAHAP 1 & $\begin{array}{l}\text { - Guru menyajikan nilai-nilai Islami yang akan } \\
\text { diimplementasikan yang berasal dari sikap } \\
\text { Rasulullah SAW yaitu Sidiq, Tabligh, Amanah dan } \\
\text { Fatonah.. } \\
\text { - Guru menyajikan topik mengenai cerita kepahlawan } \\
\text { dan tokoh Islam yang inspiratif. } \\
\text { - Guru menjelaskan gerak khas dari tari yang bertema } \\
\text { kepahlawanan yaitu ibing pencak dengan makna dan } \\
\text { nilai-nilai Islam yang terkandung di dalamnya. }\end{array}$ \\
\hline
\end{tabular}




\begin{tabular}{|c|c|}
\hline ТАНАР & PERLAKUAN GURU \\
\hline & $\begin{array}{l}\text { - Guru menjelaskan bahwa siswa akan membuat } \\
\text { simulasi dari materi yang telah diberikan dalam } \\
\text { bentuk tarian }\end{array}$ \\
\hline ТАНАР 2 & $\begin{array}{l}\text { - Guru meminta siswa membuat skenario (aturan, } \\
\text { peran dan prosedur) } \\
\text { - Guru menugaskan peran simulasi kepada siswa } \\
\text { - Guru menugaskan siswa untuk membuat gerak } \\
\text { pengembangan dari gerak dari ibing pencak dan } \\
\text { membuat gerak yang bertema kepahlawanan untuk } \\
\text { menanamkan nilai-nilai Islami. } \\
\text { - Siswa mengeksplor gerak } \\
\text { - Siswa memaknai dari setiap gerak yang dibuat }\end{array}$ \\
\hline ТАНАР 3 & $\begin{array}{l}\text { - Siswa memimpin aktifitas simulasi } \\
\text { - Guru mengawasi jalannya simulasi } \\
\text { - Siswa mendapatkan umpan balik dan evaluasi } \\
\text { (mengenai penampilan) } \\
\text { - Siswa merancang sebuah karya dari gerak yang telah } \\
\text { dibuat } \\
\text { - Siswa melanjutkan simulasi }\end{array}$ \\
\hline TAHAP 4 & $\begin{array}{l}\text { - Siswa menampilkan hasil karyanya } \\
\text { - Guru dann siswa menilai dan menyimpulkan } \\
\text { kejadian dan persepsi dari hasil karya siswa } \\
\text { - Siswa menyimpulkan kesulitan dan pandangan- } \\
\text { pandangannya } \\
\text { - Guru dan siswa menganalisis proses } \\
\text { - Guru dan siswa membandingkan aktivitas simulasi } \\
\text { dengan dunia nyata } \\
\text { - Siswa menghubungkan aktifitas simulasi dengan } \\
\text { materi pelajaran }\end{array}$ \\
\hline
\end{tabular}

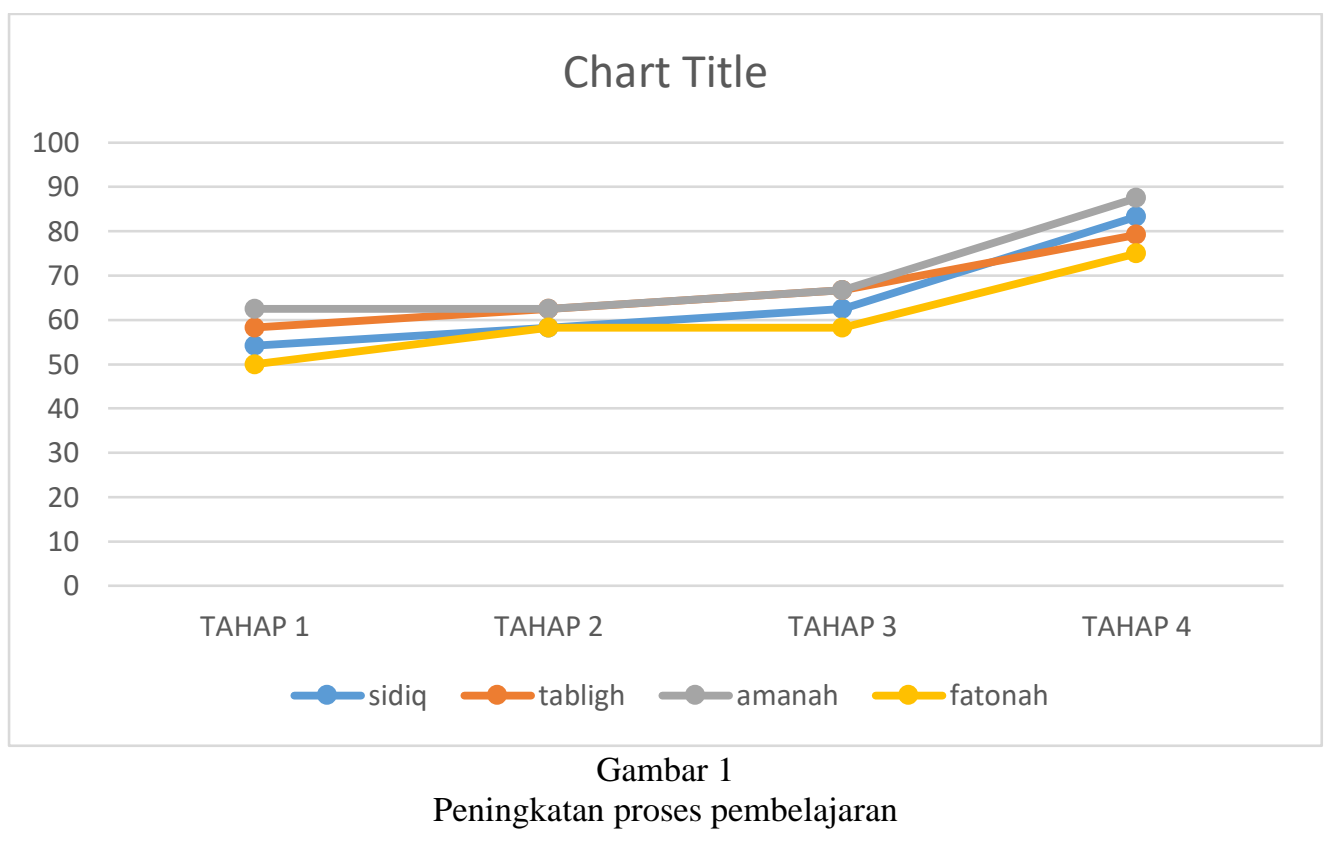

Dari grafik di atas menunjukan bahwa dari tahap pertama hingga tahap terakhir peserta didik mengalami peningkatan yang signifikan. Nilai-nilai Islami yang diimplementasikan dapat diserap oleh peserta didik. Peserta didik dapat menjadi pribadi yang ikhlas dan jujur (sidiq), sopan dan bertanggung jawab (tabligh), adil dan hormat (amanah) serta gigih dan disiplin (fatonah).

\section{SIMPULAN}

Berdasarkan hasil penelitian mengenai desain model pembelajaran tari untuk 
menerapkan nilai-nilai Islami di SMPT Manahijul Huda, maka dapat disimpulkan hasil temuan peneliti sebagai berikut.

1. Pembelajaran tari di setiap sekolah tentu memiliki perbedaan baik dalam bahan ajar, media, strategi hingga model pembelajaran yang digunakan. Pembelajaran tari yang di gunakan di SMPN 1 Kadipaten dan SMPN 2 Ciawi memiliki keunikan tersendiri. SMPN 1 Kadipaten menggunakan stimulus kesenian Marawis dengan model Instruksi Langsung, sedangkan SMPN 2 Ciawi menggunakan stimulus cerita tokoh Islam daerah setempat. Kedua sekolah tersebut menyampaikan nilainilai Islami melalui pembelajaran tari. Untuk melihat secara detail komponen pembelajaran yang digunakan dalam proses pembelajarannya, peneliti menganalisis dengan menggunakan analisis SWOT, sehingga munculah poin-poin potensial dari komponen pembelajaran yang digunakan dikedua Sekolah Menengah Pertama tersebut. Setelah dianalisis, model pembelajaran simulasi dari SMPN 2 Ciawi memiliki nilai potensial yang lebih tinggi untuk digunakan dalam pembelajaran. Namun model tersebut masih memiliki kekurangan, yakni aspek psikomotor belum muncul pada model simulasi ini. Hal tersebut karena dalam model simulasi ini guru yang lebih berperan aktif (teacher center), sehingga keterampilan siswa menjadi tidak muncul. Maka, peneliti melakukan pengembangan model untuk menghasilkan desain pengembangan model pembelajaran simulasi.

2. Desain pengembangan model pembelajaran simulasi didapatkan melalui 4 tahap, yaitu Mengidentifikasi masalah yang akan diteliti yakni mengenai pembelajaran tari yang dihindari, sebab-akibat serta solusi pemecahan masalahnya yakni menganalisis proses pembelajaran SMPN 1 Kadipaten dan SMPN 2 Ciawi yang menyampaikan pembelajaran tari dalam proses pembelajaran dengan menerapkan nilai-nilai Islami; (2) Merancang solusi terhadap permasalahan tersebut, beserta dengan program-program yang akan dilakukan dalam proses pembelajaran mulai dari tujuan hingga evaluasi serta pengembangan model pembelajaran simulasi yang digunakan SMPN 2 Ciawi untuk diimplementasikan di SMPT Manahijul Huda. Model simulasi dipilih karena model tersebut mampu meningkaptkan hasil pembelajaran tari peserta didik, namun memiliki beberapa kekurangan sehingga peneliti kembangkan; (3) Melakukan implementasi dari rancangan desain yang telah dibuat di SMPT Manahijul Huda, dilakukan secara berulang hingga mendapatkan desain yang diinginkan (siklus berulang) yakni 4 siklus dengan 6 kali pertemuan; serta (4) Meninjau kembali hasil belajar siswa untuk melihat keberhasilan desain yang dirancang. Setelah melalui empat tahap inilah, didapatkan desain pembelajaran pengembangan dari desain model simulasi yang dapat diterapkan kepada peserta didik. Pengembangan yang dilakukan meliputi komponenkomponen pembelajaran hingga menghasilkan pengembangan langkahlangkah pembelajaran model simulasi.

3. Setelah mendapatkan desain yang diinginkan, kemudian desain tersebut diuji coba dalam proses pendidikan. Ketika terdapat hal yang masih kurang dalam desain tersebut, peneliti dapat merevisi desain tersebut untuk kemudian diimplementasikan kembali kepada peserta didik. Peneliti memerlukan waktu 6 pertemuan untuk menguji coba desain pembelajaran pengembangan dari model simulasi, sehingga hasil pembelajaran peserta didik meningkat dan nilai-nilai Islami dapat dipahami dan tersampaikan dengan baik.

4. Ada beberapa implikasi berdasarkan penelitian dengan topik model pembelajaran tari berbasis nilai-nilai Islami di Kabupaten Tasikmalaya. Pertama, berkaitan dengan dengan materi seni budaya khususnya tari, kini semua sekolah baik sekolah umum maupun sekolah berbasis Islam dapat menyampaikan pembelajaran seni tari dengan materi yang berbasis Islam, seperti dalam penelitian ini mengambil stimulus bahan ajar dari cerita pahlawan dan tokoh Islam. Dari 
stimulus yang diberikan peserta didik dapat mengambil nilai-nilai Islami yang terkandung untuk diterapkan dalam kehidupan sehari-hari. Kedua, peserta didik mendapatkan pemahaman gerak tari yang berasal dari ibing pencak yang kemudian dikembangkan oleh peserta didik.

5. Berdasarkan hasil penelitian Design Based Research yang peneliti lakukan di SMPT Manahijul Huda Kabupaten Tasikmalaya, tesis ini telah berhasil menghasilkan model pembelajaran pengembangan simulasi untuk meningkatkan nilai-nilai Islami kepada peserta didik. Model pembelajaran pengembangan simulasi tersebut mengembangkan tahap-tahap serta langkah-langkah pembelajaran yang ada agar sesuai dengan pembelajaran tari untuk menerapkan nilai-nilai Islami yakni sidiq, tabligh, amanah danfatonah.

\section{DAFTAR PUSTAKA}

Aunurrahman. (2011), Belajar dan Pembelajaran. Bandung: ALFABETA.

Cahyo, N.A. (2013). Panduan Aplikasi Teori-teori Belajar Mengajar Teraktual dan Terpopuler. Yogyakarta: Diva Press

Chrisiana, Wanda. (2005). Upaya penerapan pendidikan karakter bagi mahasiswa. Jurnal Teknik Industri vol.7 no.1, 8390

Elmubarok, Zaim. (2009). Membumikan Pendidikan Nilai Mengumpulkan yang Terserak, Menyambungkan yang Terputus, dan Menyatukan yang Tercerai. Bandung: ALFABETA.

Hermawansyah. (2015). "Pendidikan Karakter Berbasis Nilai-nilai Islam". Jurnal Ilmiah kreatif vol. XII No. 1 Januari 2015.

Johansyah Lubis dan Hendro Wardoyo. (2014). Pencak Silat: Panduan Praktis. Jakarta: PT RajaGrafindo Persada

Joyce, B dan Weill, M. (2009). Models of Teaching (2nd ed). Yogyakarta: Pustaka Pelajar.

Juju Masunah dan Tati Narawati. (2003). Seni dan Pendidikan Seni Sebuah Bunga Rampai. P4ST UPI: Bandung.
Kasmahidayat, Yuliawan. (2010). Agama dalam Transformasi Budaya Nusantara. Bandung: Bintang WarliArtika.

Koentjaraningrat. (2011). Pengantar Antropologi I. Jakarta: Rineka Cipta.

Maeearif, Syafie I. (1991). Pendidikan Islam di Indonesia antara Cita dan Fakta. Yogyakarta: PT. Tiara Wacana.

Masunah, Juju. (2012). Tari Pendidikan. Bandung.

Mulyana. (2014). Pendidikan Pencak Silat Membangun Jati Diri dan Karakter Bangsa. Bandung: PT Remaja Rosdakarya

Mulyasa. (2011). Manajemen Pendidikan Karakter. Jakarta: Bumi Aksara.

Notosoejitno. (1997). Khazanah Pencak Silat. Jakarta: Infomedika.

Plomp, T., \& Nieveen, N. (2007). An introduction to educational design research. In Proceedings of the Seminar Conducted at the East China Normal University, Shanghai (PR china), November 23-26, 2007. Enschede: Netherlands Institute for Curriculum Development.

Pribadi, Benny A. (2009). Langkah Penting Merancang kegiatan Pembelajaran yang Efektif dan Berkualitas Model Desain Sistem Pembelajaran. Jakarta: Dian Rakyat.

Pupuh Faturrohman dkk. (2013). Pengembangan Pendidikan Karakter. Bandung: Refika Aditama.

Tobroni. (2008). Pendidikan Islam Paradigma Teologis, Filosofis dan Spritualitas. Malang: UMM, Press,

rianto. (2009). Mendesain Model Pembelajaran Inovatif-Progresif. Jakarta: Kencana.

Toto Ruhimat dkk. (2009). Kurikulum dan Pembelajaran. Bandung: FIP UPI.

Yuliawan Kasmahidayat dan Isus Sumiaty. (2010). Ibing Pencak Sebagai Materi Pelajaran. Bandung: CV. Bintang WarliArtika.

Yusuf, Syamsu. (2009). Psikologi Perkembangan Anak dan Remaja. Bandung: Remaja Rosdakarya. Cetakan Ke-10. 